\title{
Impact of Ifrs Adoption on Accountability of Nigerian Organisations
}

\author{
Dr. Patrick .I. Zaiyol ${ }^{1}{ }^{\text {EgwuAchor Andrew }}{ }^{2,}$ Benjamin \\ MemgaUdende ${ }^{3}$ \\ ${ }^{I}$ Department of Accounting and Finance, Faculty of Management Sciences, University of \\ Agriculture, Makurdi, Nigeria \\ ${ }^{2}$ Department of Business Education, College of Education Oju, Benue State, Nigeria.PMB: \\ 2035 Otukpo, \\ ${ }^{3}$ RevenueDepartment ,Ukum local government secretariat, Sankera Benue state, Nigeria.
}

\begin{abstract}
The adoption of IFRS around the world is gaining popularity with Nigeria not being an exception. It brings about improvement in accountability and quality of accounting information through a uniform set of standards for financial reporting. However, accountability is a function of the firm's overall institutional setting. This paper examines whether the adoption of International Financial Reporting Standards (IFRS) improves accountability and quality of accounting information of companies in Nigeria. The study specifically investigates whetherthe quantitative differences in the financial reports prepared by Nigerian listed companies under SAS and IFRS are statistically significant or not. Secondary data were employed from annual reports of companies in Nigeria using key financial statement content in terms of earning per share, profit for the year and number of disclosureas a means for comparison.Two hypotheses was developed and tested at five (5) per cent level of significance.Findings revealed that the quantitative differences in the financial reports prepared underSAS and IFRS are statistically significant. The study therefore concludes that IFRShave impacted on accountability and quality of information from financial statement of Nigerianorganization.
\end{abstract}

Keywords:International Financial Reporting Standards (IFRS), Accountability, IFRS adoption, information quality, statement of accounting standard (SAS)

\section{Introduction}

According to Masud (2013,[15]) The Federal Executive Council of Nigeria approved the convergence of Nigerian SAS with IFRS effective January 1, 2012. The adoption was to ensure all stakeholders use IFRS by January 2014. According to the IFRS adoption Roadmap Committee (2010) in Olugbenga et al (2016,[17]), Companies listed on the Nigerian stock exchange are expected to adopt the IFRS by January 2012. Significant Public Interest Entities are expected to adopt IFRS for financial year commencing 1st January 2013 while Small and Medium-sized Entities (SMEs) have 2014 January as their compliance date.

The IFRS (International Financial Reporting Standards) consists of a set of international accounting principles, the adoption of which aims at establishing clear rules originally within the European Union to draw up comparable and transparent annual reports and financial statements (Cardozza, 2008,[6]). Their adoption represents an essential element to obtain an integrated, competitive and attractive beyond the European capital markets.

Basically, knowing the anticipated benefits to be derived as a result of the change from statement of accounting standard (SAS) to IFRS in terms of improved accountability and quality of financial reporting is the core motive of the proponents of general adoption of IFRS. 
The International Accounting Standards Board's (IASB) IFRS Framework states that; "The objective of financial statements is to provide information about the financial position, performance and changes in financial position of an entity that is useful to a wide range of users in making economic decisions",(IASB 2010,[11]).According to (Sloan $2001,[21])$ the financial statement is the first source of independent and true communication about the performance of managers. To be able to meet the needs of the users, the financial statements must not only comply with the International Financial Reporting Standards (IFRS), but also be of high quality. The quality of financial reports is measured using four key qualitative characteristics of financial information embedded within the Framework for the Preparation and Presentation of Financial Statements issued by International Accounting Standards Board (IASB 2010,[11]). These qualitative characteristics are relevance, faithful representation, comparability and understandability. These qualities translate into accountability. According to the (IASB 2010,[11]) relevance and faithful representation are the fundamental qualities, whilst comparability and understandability are enhancing qualities. The Framework states that the qualitative characteristics are the attributes that make the information provided in financial statements useful to users. Accounting information has the quality of relevance when it makes a difference in a business decision; it provides information that has predictive value and has confirmatory value (IASB 2010,[11[).

Most studies on IFRS have concentrated on it as a financial reporting issue. But financial reporting is one aspect of the total impact of IFRS composition. Much more significant is the impact of a set of standards on a company's organization, accountability philosophy, business structure compliance to the standards, performance management, and internal control and so on. The objective of the study is to examine whether financial reports prepared in compliance with IFRS legal and professional framework enhances best practice in corporate organization.

\subsection{Objectives Of The Study}

The main objective of the paper is to focus on the adoption and application of IFRS and benefit arising thereof. The specific objectives are-

1 To portray the role of IFRS in accountability of Nigerian organisation

2 To portray the role of IFRS for quality accounting information;.

\subsection{Research Question:}

The following questions guided the study:

1 Does the adoption of IFRS impact on accountability of Nigerian organisations?

2 Does the adoption of IFRS impact on the quality accounting information?

\section{3research Hypothesis}

\section{Hypothesis 1}

Ho: There is no significant relation between IFRS adoption and accountability of organisations in Nigeria.

H1: There is significant relation between IFRS adoption and accountability of organisations in Nigeria

\section{Hypothesis 2}

Ho: There is no significant relation between IFRS and the quality of information.

H1: There is significant relation between IFRS and the quality of information.

\section{Literature Review}

This section will look at, conceptual and theoretical review on the adoption of IFRS in Nigeria.

\subsection{Conceptual Framework}

International Financial Reporting Standard (IFRS) are standards, interpretation and the framework adopted by International Accounting Standards Board; International Financial Reporting Standards are products of private sector initiatives towards the harmonization and 
internationalization of financial reporting in response to the demands of business globalization and regional convergence (Abata, 2015,[1]). International Financial Reporting Standards (IFRS) are body of prescriptive rules and guidelines with global reach and appeal which provide direction and guidance on how business enterprises in a globalized world could achieve the goal of proper record keeping, transparency, uniformity, comparability and enhancing public confidence in financial reporting (Tendeloo and Vanstraelen, (2005,[22]). Thus, failure on the part of the firm to apply the requirements of IFRS would result in inconsistencies, lack of accountability and transparency, distortion in financial reports, which in turn results into poor financial reporting practices and dissemination of accounting information that is of less value to any particular group of users.

IFRS represent a single set of high quality, globally accepted accounting standards that can enhance comparability of financial reporting across the globe. This increased comparability of financial information could result in better investment decisions and ensure a more optimal allocation of resources across the global economy (Jacob and Madu, 2009,[12]).The preparation and presentation of financial statements will be bereft of objectivity, reliability, credibility and comparability, and thus results in fraudulent business practices which subsequently lead to business failure and become devastating on the national economy (Atu et al., 2014,[2]).

\subsubsection{Adoption ofIfrs}

According to Kenneth $(2012,[14])$, the quality of financial reporting is indispensable to the need of users who requires them for investment and other decision making purposes. Financial reports can only be regarded as useful if it represents the "economic substance" of an organization in terms of relevance, reliability, comparability and aids interpretation simplicity.Before IFRS adoption era, most countries had their own standards with local bodies responsible for developing and issuance. The Nigerian Accounting Standards Board (NASB) was responsible for developing and issuing standards known as Statements of Accounting Standards (SAS) and in the new dispensation, the body was renamed Financial Reporting Council (FRC) of Nigeria as the regulatory body overseeing the adoption and implementation IFRS (Kenneth, 2012,[14]). The adoption and implementation of the international standards in a country takes place in an environment that is affected by factors unique to that country, for example, the economy, politics, laws and regulations, and culture. A reason that seems to cut across countries for not fully incorporating IFRS is the irresistible urge to amend the international standards to provide for national specificities. The magnitude of cross-border financing transitions, securities trading, and direct foreign investments shows the need for a single set of rules for recognizing and measuring assets, liabilities, and income. El-Gazzar et al. $(1999,[8])$ state that IFRS provide answers to this issue because financial disclosures prepared in compliance with IASs can facilitate comparison

\subsubsection{Challenges That Necessitate Ifrs Adoption in Nigeria}

Presently, GAAPs are significantly wearing out and becoming obsolete therefore making financial reports difficult to be compared with financial statements of other jurisdiction. Nigeria in adopting IFRS(Fowokan, 2011,[9]). The reasons for this include:

- Difficulties in comparing financial statements globally.

- Difficulties in consolidating financial statement of a group companies.

- High cost of preparing and presenting group financial statements.

- High cost of accessing capital in the foreign capital market

- Inability of the users of financial statements to comprehend very well, the information in multinational company's financial reports.

- Decline in the inflow of the foreign direct investment in Nigeria.

- Unattractive and Uncompetitive capital market because of lack of quality financial information due to poor local standards in reporting financial statement. 


\subsubsection{Benefits of Adopting Ifrs}

According to the Report of the Committee on Road Map to the Adoption of IFRS in Nigeria $(2011,[20])$ the benefits of IFRS adoption are numerous. In general, it offers organisations opportunity for a fresh look at their processes and policies. It also gives room for one basis of accounting (simplify local statutory reporting, cross-border transactions, strengthening of controls and efficiencies in future reporting). Furthermore, it may lead to standardization of practices across countries (that is, consistency of global accounting policies and procedures, shared service center deployment and streamlined merger and acquisition activities). Finally, it can lead to improved comparability across borders and within global industries, with worldwide peers and competitors. A more specific consideration may reveal individual benefits as hereunder:

- International Investors: Ability to make useful and meaningful comparisons of investments portfolios in different countries.

- Multi-national Companies: Easy consolidation of financial statements; Better management control; as harmonisation would aid internal communication of financial information; and Easier to comply with the reporting requirements of overseas stock exchanges.

- $\quad$ Regional economic groups (e.g. ECOWAS, etc.) :Promotion of trade within the region through common accounting practices; and Ability to compile meaningful data on the performance of various enterprises within the region.

- Governments and National standard setting bodies: Assist governments in attracting international investors as adoption of IFRS enables international investors easy monitoring of overseas investments.

- Local and domestic companies:Easier access to external capital; Global comparability of financial statements; and Transparency and enhanced disclosures and seal of quality.

\subsubsection{Challenges to IFRS Implementation}

According to Herbert et al. $(2014,[10])$ the implementation of IFRS provokes a plethora of development issues and challenges. The leading candidates can be compactly summarized under three categories, namely: bounded rationality challenges, process challenges, and technical challenges.Bounded rationality Challenges: These are mainly deposited in the firm's staff and involve their capacity to take on idiosyncratic skills and competencies required by IFRS. Technical capacity is a basic requirement for effective implementation of IFRS. "Countries that implement IFRS face a variety of capacity-related issues, depending on the approach they take. One major challenge encountered in the implementation process is the shortage of skilled accountants and auditors who are technically competent in implementing IFRS and ISAs" (United Nations 2008 in Herbert et al., $2014,[10])$. Where the firm's human resources are limited in knowledge, skill, foresight and time, these will have implications for the achievement of human purpose and for economic organization of IFRS. In this regard, inadequate internal staff, poor resource deployment, change management issues, inadequate training, inadequate top management and board support, and poor incentive structure, are bounded rationality challenges inherent in human behaviour. Juxtapose these with uncertainty and complexity of business, bounds on rationality become further stretched.

Process challenges:are usually resident in the nature of enterprise and business performance. IFRS implementation in an environment of poor business performance is bound to be prolonged or fail totally.Technical challenges:are related to both bounded rationality and process management. Transactional disabilities are implicit in the presence of scarce resources, poor skills functionality and poor application management. Process and technical impediments also resonate with the intricacies of IFRS technical accounting standards, the overlap of local and international regulatory considerations, the required conversion across business units and countries, and the level of information technology (IT) infrastructure required in the organization and the dearth of IT professionals with IFRS technical knowledge 
who can interpret and translate IFRS into IT changes. An organization that lacks men of resource will invariably lack the ability to deal resourcefully with unusual problems.

A proper implementation plan should begin with an evaluation of the firm's internal organizational strengths, skills and weaknesses in terms of availability and capacity of human resources. IFRS implementation introduces complexity into the accounting environment and the firm may be required to progressively improve its internal controls as a first step. A seamless transition to IFRS platform must overcome these challenges. Both government and many Nigerian companies underestimate the level of technical expertise required to transit to IFRS. IFRS requires idiosyncratic skills, and these are in short supply. Because it demands basic understanding of accounting, a successful implementation requires a lot of training and re-orientation for all professional accountants in Nigeria. IFRS is complex and requires huge resources in both finance and time respects for intensive skills training and acquisition, and to recalibrate organizational systems and processes. Given the country's acute infrastructure deficits, the transition challenge is certainly beyond what many SPEs bargained for, which explains why most of them are finding implementation very daunting and arduous.

\subsubsection{Concept Of Accountability}

Zahran (2011,[23]) "Accountability is the obligation of the Organization and its staff members to be answerable for delivering specific results that have been determined through a clear and transparent assignment of responsibility, subject to the availability of resources and the constraints posed by external factors. Accountability includes achieving objectives and results in response to mandates, fair and accurate reporting on performance results, stewardship of funds, and all aspects of performance in accordance with regulations, rules and standards, including a clearly defined system of rewards and sanctions."

A framework for Human Resource Management Glossary definition of Accountability (2001) in Zahran (2011,[23]) "Concept which implies taking ownership of all responsibilities and honouring commitments; delivering outputs for which the staff member has responsibility within prescribed time, cost and quality standards; operating in compliance with organizational regulations and rules; supporting subordinates, providing oversight and taking responsibility for delegated assignments; taking personal responsibility for personal shortcomings and, where applicable, those of the work unit."UNDP (2008) in Zahran $(2011,[23])$ "Accountability is the obligation to (i) demonstrate that work has been conducted in accordance with agreed rules and standards and (ii) report fairly and accurately on performance results vis-à-vis mandated roles and/or plans."

UNFPA Accountability Framework (2007) in Zahran (2011,[23]) “Accountability is the process whereby public service organizations and individuals within them are held responsible for their decisions and actions including their stewardship of public funds, fairness, and all aspects of performance, in accordance with agreed rules and standards, and fair and accurate reporting on performance results vis-à-vis mandated roles and/or plans. In other words, it means that those in charge of UNFPA programmes, activities and guidance are held accountable for efficient and effective management." Brown and Moore $(2001,[5])$ states that accountability should be understood as a strategic choice, not just as a legal or moral imperative "The issue of accountability arises because various stakeholders believe that they have the moral and legal right (as well as the effective power) to make claims on what the organisation does with its bundle of assets. The problem of accountability arises because the claims of the various stakeholders are not necessarily coherently aligned with one another. Nor do they necessarily align perfectly with those that lead and staff the organisation.As a result, the leadership must make choices to embrace or resist particular stakeholder demands". The manner in which an organisation structures its accountabilities will thus have a profound impact on its mission, strategy and operations. It follows that leaders in organisations must make three crucial calculations if their organisations are to survive, provide socially valuable results, and successfully adapt to changing circumstances. 
According to Regan and Cronin $(2012,[7])$ accountability cycle is thus:

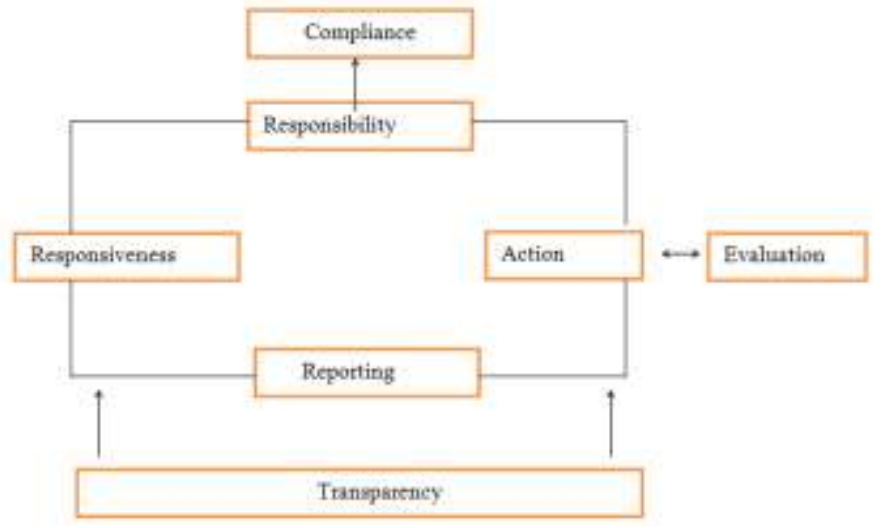

The elements in the cycle of accountability are now broken down further:

\section{Responsibility}

- There is needs to be clarity of roles and responsibilities for all concerned;

- Appropriate action must be taken if responsibilities are not fulfilled;

- Clear boundaries must indicate who is responsible to whom, and for what;

- Compliance concerns the duty to comply with agreed standards regarding both organisational policies and practices, and the reporting of policies and performance.

\section{Action and evaluation}

- Monitoring is the process by which implementation is checked to ensure it is being done according to plan, and is a comparison between planned and actual results at the activities and outputs level.

- Evaluations are more thorough investigations into the difference between planned and actual results, and question the purpose of the project or programme to see if it contributed to reaching the goal.

- Any policy, commitment or code of conduct is only as good as the ability and willingness of the stakeholders to put it into practice;

- Accountability therefore needs to be embedded in the governance and management of organisations;

- Impacts should be measured as objectively as possible;

- Financial accountability is concerned with ensuring that stakeholders, funds are not misused.

\section{Reporting}

- There is great importance attached to the responsibility to provide an account of one's actions;

- This account must be based on factual and balanced information;

\section{Responsiveness}

- Responsiveness concerns the responsibility of the organisation for its acts and omissions, including the processes of decision-making and the results of these decisions;

- There needs to be a concerted effort to seek and hear the views,particularly those of primary stakeholders.

- Feedback on responses enacted is also very important;

- Being accountable to others, organisations need to be both transparent and open to change, but also those outside of the organisation must be interested and empowered to respond;

\section{Transparency}


- Transparency concerns the openness and accessibility through which organisations account to those with a legitimate interest - the stakeholders in the organisation;

- Transparency does not lead automatically to accountability; it serves as a tool to open officials and other responsible parties up to wider scrutiny. Much depends on what information is sought, by whom, and for what purpose;

\subsubsection{Ifrsand Accountability}

The fundamental economic function of accounting standards is to provide "agreement about how important commercial transactions are to be implemented" (Ball, 2001,[3]). Ensuring disclosure quality of financial information is also mandatory for reducing information asymmetry and solving agency problem in corporate sector.Barth et al.,(2006,[4]); IFRS is used to improve accountability of managers to shareholders and it can be evidenced by proper assets and earnings management, lower cost of capital, and high forecasting capability by the investors about firm's future earnings.

In a developing economy, we can figure out the following prospects that may accrue by the adoption of IFRS:

1. The adoption may have some direct impact on the corporate sector. Agency problem between management and shareholders can be substantially reduced through implementation of IFRS as increased transparency causes managers to act more in the interests of the shareholders. The increased transparency promised by IFRS also could cause a similar increase in the efficiency of contracting between firms and lenders. The increased transparency and loss recognition timeliness promised by IFRS could increase the efficiency of contracting in debt markets, with potential gains to equity investors in terms of reduced cost of debt capital.

2. The vulnerability of small investors is a long time established problem and undoubtedly it is a big impediment for the stock market development. Small investors are less likely than investment professionals to be able to anticipate financial statement information from other sources. IFRS adoption could reduce the cost of investors of processing financial information. Improving financial reporting quality allows the small investors to compete better with professionals, and hence reduces the risk they are trading with a better-informed professional.

3. Another improvement of adopting IFRS to reduce information asymmetry in the corporate sector can arise due to its emphasis on fair value accounting (FVA). Most economists argue that fair value incorporates more information into the financial statements than historical costs. Though other conditions are not favorable for implementing FVA (like achieving observable market prices or independently observable, accurate estimates of liquid market prices that cannot be materially influenced by managers due to less perfect market liquidity), still FVA can make financial statements more informative, with potential advantages to investors, and if enforceable more useful for purposes of contracting with lenders, managers and other parties.

4. Apart from these, adoption of IFRS can reduce accounting diversity thus will encourage the foreigners for cross border investment which in turn may improve the liquidity of the capital markets and enlarge firm's investor base to improve risk-sharing and lowers cost of capital

5. Prevailing local GAAP is not enough to ensure proper disclosure quality and there are ambiguities among numerous rules, guidelines and notifications that are often selfcontradictory and perplexing to one another.

6. Mandatory adoption of IFRS will reduce such vagueness and create more binding on the firms to perform their disclosure responsibility thereby improving accountability. 


\subsection{Theoretical Review}

\section{The economic theory of networks:}

Katz and Shapiro (1985,[13]) state that "there are many products for which the utility that user derives from consumption of the good increases with the number of other agents consuming the good". They argued that the key idea in network theory is that a network dependent product's benefits depend upon the number of the other users who are in the same network. They draw a distinction between direct value of the product and network-related value. The authors pointed out that the direct value is generated through a direct physical effect of the number of purchasers on the quality of the product. Regarding the network related value, Katz and Shapiro $(1985,[13])$ considered that a product can be adopted or used even if its direct value is inferior to that of a substitute product. The economic literature sometimes calls the direct value autarky value, while the network-related value is referred to as synchronization value. It is noteworthy that a single set of high quality accounting standards would provide considerable support for international investors to evaluate the performance of companies across national boundaries .That is, IFRS standards are likely to lower transaction costs for foreign users of financial statements (Ramanna and Sletten, $2010,[19])$. From the perspective of economic theory of networks, the benefits that a given country derives from IFRS adoption can be explained by the magnitude of its economic relations with other partner-countries that have already adopted IFRS. In this sense, IFRS standards are considered a network-dependent product

\section{Accountability Theory.}

According to Nnaemeka and Rotimi (2012,[16]) Accountability is a concept in ethics with several meanings. Regarding corporate governance it means the ethical responsibility to provide an account or reckoning of the actions for which one is held responsible. The contribution of corporate accountability theory is that it helps define the nature of the relationship between corporate managers and the rest of society. It also sets out the arguments as to why companies should report on their environmental, social, and economic performance, not just financial performance. The early '90s have brought in corporate reporting a new trend of sustainability reporting. The new concept has been adopted especially by the multinational companies. These companies had reorganized their disclosure policy and nearby financial information they started to disclose information regarding their economic, environment and social performance.

\section{Pure - Impression - Management Model Theory}

Popa et, al. (2009,[18])PIMM theory of accounting propounded by Keppler in 1995, the theory states that accountability serves as a linkage construct by continually reminding people of the need to:

1. Act in accordance with the prevailing form and content of financialreporting.

2. Advance compelling, justification/excuses for conduct that deviate from the form and content of financial reporting.

In the real sense, financial reporting cannot be accepted by general public orwould be investors if certain guidelines/standards that are generally expected are notfollowed and observed. This theory on the other hand, recognizes that uniformity andobservance of relevant standards are meant for the smooth functioning of the publiccompanies.

\section{Appling the PIMM theory}

This theory is relevant to this study in that it focuses on behaviouralaspect of accounting. Accountability is the missing link in the seemingly perpetual level of analysis controversy, the connection between individual decision makers and thecollectives within which they live and work.

The concept accountability serves as a linkage construct by continually remindingpeople of the need to:

a. Act in accordance with the prevailing norms.

b. Advance compelling justifications or excuses for conducts that deviates fromthose norms. 
The PIMM recognizes that a large measure of trust and self-accountability isnecessary for the smooth functioning of institutions. Therefore, if PIMM ofaccountability is properly utilized by the management of companies or institutions inNigeria, it will fetch a good result on public accountability (Popa et, al., 2009,[18]).

\section{Research Methods}

The purpose of this study is to evaluate the impact of IFRS on accountability of Nigerian organizations and its impact on the quality of information. To users of financial statements, one of the ways by which IFRS impacts financial reporting is by ensuring comparability of financial reports amongst companies either within the same industry, countries or countries. Nigerian listed companies were the focus of this paper because of its role in the economy. Twenty listed companies were randomly selected to make generalization on the findings.Comparability is the major impact IFRS has brought to financial reporting. This study tends to measure the quantitative impact on financial statement comparing the NGAAP and IFRS financial statement (2011 NGAAP and 2015 IFRS). The major key content of financial statement is, earning per share, number of disclosure and profit for the year.

Data was collected from the audited financial statements of twenty listed companies in Nigeria directly from their websites. A Pearson correlation coefficient was used to analyze the relationship between the IFRS and NGAAP.

\section{Discussion Of Results And Analysis}

Table 1:Descriptive statistics for accountability and quality of disclosure for pre IFRS presentation

\begin{tabular}{|c|c|c|c|}
\hline \multicolumn{4}{|c|}{ Descriptive Statistics } \\
\hline & Mean & Std. Deviation & $\mathrm{N}$ \\
\hline Share capital & 7.36087 & 2.109998 & 20 \\
\hline EPS & 13.6065 & 26.93512 & 20 \\
\hline No. of Disclosure & 11.1205 & 13.92623 & 20 \\
\hline Profit for the year & 2.15737 & 5.633537 & 20 \\
\hline
\end{tabular}

\section{SPSS Output, 2014}

Table 2: Pearson correlation (r) coefficient of accountability and quality of disclosure for pre IFRS presentation

\begin{tabular}{|l|l|l|l|l|l|}
\hline & & $\begin{array}{l}\text { Share } \\
\text { Capital }\end{array}$ & EPS & $\begin{array}{l}\text { No. } \\
\text { Disclosure }\end{array}$ & $\begin{array}{l}\text { Profit for } \\
\text { the year }\end{array}$ \\
\hline \multirow{5}{*}{ Share capital } & Pearson Correlation & 1 & -.140 & .006 & .060 \\
\cline { 2 - 6 } & Sig. (2-tailed) & & .556 & .979 & .802 \\
\cline { 2 - 6 } & $\mathrm{N}$ & 20 & 20 & 20 & 20 \\
\hline \multirow{5}{*}{ EPS } & Pearson Correlation & -.140 & 1 & -.254 & -.147 \\
\cline { 2 - 6 } & Sig. (2-tailed) & .556 & & .281 & .537 \\
\cline { 2 - 6 } & $\mathrm{N}$ & 20 & 20 & 20 & 20 \\
\hline \multirow{3}{*}{ Profit for the year } & Pearson Correlation & .006 & -.254 & 1 & -.287 \\
\cline { 2 - 6 } & Sig. (2-tailed) & .979 & .281 & & .220 \\
\cline { 2 - 6 } & $\mathrm{N}$ & 20 & 20 & 20 & 20 \\
\cline { 2 - 6 } & Pearson Correlation & .060 & -.147 & -.287 & 1 \\
\cline { 2 - 6 } & Sig. (2-tailed) & .802 & .537 & .220 & \\
\cline { 2 - 6 } & $\mathrm{N}$ & 20 & 20 & 20 & 20 \\
\hline
\end{tabular}

Source: Sample Company's 2011 annual reports, SPSS Output, 2014

** Correlation is significant at the 0.05 level (2-tailed) 
Table 3: Descriptive statistics for accountability and quality of disclosure for pre IFRS presentation

\begin{tabular}{|l|l|l|l|}
\hline & Mean & Std. Deviation & N \\
\hline Share capital & 7.5491 & 2.105278 & 20 \\
\hline EPS & 12.2500 & 42.50819 & 20 \\
\hline No. of Disclosure & 24.6000 & 14.14362 & 20 \\
\hline Profit for the year & 1.4138 & 7.069026 & 20 \\
\hline
\end{tabular}

\section{SPSS Output, 2014}

Table 4 :Pearson correlation ( $r$ ) coefficient of accountability and quality of disclosure for post IFRS presentation

\begin{tabular}{|c|c|c|c|c|c|}
\hline & & Share capital & EPS & $\begin{array}{l}\text { No. of } \\
\text { Disclosure }\end{array}$ & $\begin{array}{l}\text { Profit for } \\
\text { the year }\end{array}$ \\
\hline \multirow[t]{3}{*}{ Share capital } & Pearson Correlation & 1 & -.046 & -.177 & $-.509^{*}$ \\
\hline & Sig. (2-tailed) & & .846 & .457 & .022 \\
\hline & $\mathrm{N}$ & 20 & 20 & 20 & 20 \\
\hline \multirow[t]{3}{*}{ EPS } & Pearson Correlation & -.046 & 1 & .267 & .060 \\
\hline & Sig. (2-tailed) & .846 & & .254 & .803 \\
\hline & $\mathrm{N}$ & 20 & 20 & 20 & 20 \\
\hline \multirow[t]{3}{*}{ No. of Disclosure } & Pearson Correlation & -.177 & .267 & 1 & .438 \\
\hline & Sig. (2-tailed) & .457 & .254 & & .054 \\
\hline & $\mathrm{N}$ & 20 & 20 & 20 & 20 \\
\hline \multirow[t]{3}{*}{ Profit for the year } & Pearson Correlation & $-.509^{*}$ & .060 & .438 & 1 \\
\hline & Sig. (2-tailed) & .022 & .803 & .054 & \\
\hline & $\mathrm{N}$ & 20 & 20 & 20 & 20 \\
\hline
\end{tabular}

\subsection{Test of Hypotheses}

Table 5 :Paired Samples for EPS OF pre and post IFRS

\begin{tabular}{|c|c|c|c|c|c|c|c|c|}
\hline & \multicolumn{5}{|c|}{ Paired Differences } & \multirow[t]{3}{*}{$\mathrm{T}$} & \multirow[t]{3}{*}{$\mathrm{df}$} & \multirow{3}{*}{$\begin{array}{l}\text { Sig. (2- } \\
\text { tailed) }\end{array}$} \\
\hline & \multirow[t]{2}{*}{ Mean } & \multirow[t]{2}{*}{$\begin{array}{l}\text { Std. } \\
\text { Deviation }\end{array}$} & \multirow{2}{*}{$\begin{array}{l}\text { Std. } \\
\text { Error } \\
\text { Mean }\end{array}$} & \multicolumn{2}{|c|}{$\begin{array}{l}95 \% \text { Confidence Interval } \\
\text { of the Difference }\end{array}$} & & & \\
\hline & & & & Lower & Upper & & & \\
\hline $\begin{array}{l}\text { Post IFRS1 - Pre } \\
\text { IFRS }\end{array}$ & $\begin{array}{l}6.1978 \\
50\end{array}$ & 52.886949 & $\begin{array}{l}11.825 \\
881\end{array}$ & -18.554004 & $\begin{array}{l}30.94970 \\
4\end{array}$ & .524 & 19 & .606 \\
\hline
\end{tabular}

Source: Sample Company's 2015 annual reports, SPSS Output, 2014

** Correlation is significant at the 0.05 level (2-tailed)

Table 6 :Paired Samples for number of disclosure OF pre and post IFRS

\begin{tabular}{|c|c|c|c|c|c|c|c|c|}
\hline & \multicolumn{5}{|c|}{ Paired Differences } & \multirow[t]{3}{*}{$\mathrm{T}$} & \multirow[t]{3}{*}{ df } & \multirow{3}{*}{$\begin{array}{l}\text { Sig. } \\
\text { (2- } \\
\text { tailed) }\end{array}$} \\
\hline & \multirow[t]{2}{*}{ Mean } & \multirow[t]{2}{*}{$\begin{array}{l}\text { Std. } \\
\text { Deviation }\end{array}$} & \multirow{2}{*}{$\begin{array}{l}\text { Std. } \\
\text { Error } \\
\text { Mean }\end{array}$} & \multicolumn{2}{|c|}{$\begin{array}{l}\text { 95\% Confidence Interval of the } \\
\text { Difference }\end{array}$} & & & \\
\hline & & & & Lower & Upper & & & \\
\hline $\begin{array}{l}\text { Post IFRS1 - } \\
\text { Pre IFRS }\end{array}$ & $\begin{array}{l}13.500 \\
000\end{array}$ & 16.947287 & $\begin{array}{l}3.78952 \\
9\end{array}$ & 5.568426 & $\begin{array}{l}21.4315 \\
74\end{array}$ & $\begin{array}{l}3.5 \\
62\end{array}$ & 19 & .002 \\
\hline
\end{tabular}

Source: Sample Company's 2015 annual reports, SPSS Output, 2014

** Correlation is significant at the 0.05 level (2-tailed)

\section{Hypotheses 1}

Ho1: There is no significant relation between IFRS adoption and accountability of organisations in Nigeria.

This hypothesis (Ho1) was tested using the paired sample correlation test of the post and pre IFRS EPS and disclosure level.

The mean of 6.2, standard deviation of 52.887 and standard error mean of 11.2 inTable 5, suggest thatadoption of IFRS has no impact on the EPS of the company. This argument is 
strengthened by the significance of 0.606 which is more than the 0.05 significance level. For paired sample of number of disclosure, the mean of 13.5, standard deviation of 16.947 and standard error mean of 3.7895 in Table 6, indicates that the adoption of IFRS has a significant impact on the quality of disclosure. This is also strengthened by the significant level of 0.02 which is below the 0.05 level of significance. Also in table 4 and table 2, it can be seen that the Pearson correlation decrease from 0.06 to -0.177 depicting a reverse relationship of disclosure level on share capital as a result of adoption of IFRS. From the test, Ho1 will be rejected and $\mathrm{HI}$

Will be accepted showing that there is a relationship between accountability of organizations and adoption of IFRS.

\section{Hypotheses 2}

This hypothesis (Ho2): There is no significant relation between IFRS and the quality of information was tested comparing the Pearson correlation of post and pre IFRS information.

Table 2 and 4 indicates the relationship between the variables used for pre and post IFRS analysis. It shows that number of disclosure is negatively related to profit for the year under pre IFRS and positively related under post IFRS at -0.287 and 0.438 respectively

It simply implies that disclosure and profit for the year has a higher positive relationship under post IFRS.

The aggregate result from the post IFRS Pearson correlation analyses reveal that $\mathrm{P}$ value overall in the result indicates that post IFRS financial information has a correlation. However, the elements that made up financial information are not independent of other indicators in post IFRS adoption thereby giving a low cumulative relationship to share value.

Therefore the null hypothesis is rejected and it is concluded that IFRS is highly associated with information quality because of its statistical significance between the variables considered.

This finding conforms to the work of Abata (2015,[1]) thattheadoption of IFRS has significant impact on quality of information of Nigeria listed companies.

\subsection{Conclusion}

\section{Conclusion And Recommendations}

In this study, attempts were made to examine impact of IFRS adoption on the accountability and quality of financial statements comparability as evident from

Nigerian listed companies. Two hypotheses were developed and tested through Pearson correlation coefficient and paired sample statistics. Based on the overall result of the analysis, it could therefore be concluded that adoption IFRS enhances accountability of financial statements and improves financial information quality.

\subsection{Recommendations}

Having carried out analysis on the study, and find out that the adoption of IFRS has a significant impact on the accountability and quality of financial information, it is therefore recommended that:

1. Organisations should ensure that corporate governance is strongly implemented since it ensures the quality of earnings. IFRS should be adopted not just in form but in substance

2. Organisations should provide all necessary resources needed to understand the impact of IFRS on their organisation and train staff on IFRS and changes in accounting framework

3. Management and professional bodies should work together to tighten compliance in the Nigerian DMBs in order to enhance the impact of IFRS. Enforcement is better than the standard setting itself as rigid regulation and enforcement could bring out the benefit of IFRS.

4. Government should empower the financial reporting council of Nigeria (FRCN) to monitor and enforce standards and training to smoothen the introduction of International Financial Reporting Standards (IFRS). This process will enhance credible and qualitative 
financial statements, engendering growth and development of capital market, which will stir up the need to embrace and practice IFRS in Nigeria.

5. The Financial Reporting Council in conjunction with various professional bodies should place more premium on continuing professional education and training. As much as possible, the professional accountancy bodies should align their continuing professional education requirements with IFAC guidelines.

\section{References}

[1]. Abata. A.M. (2015) the impact of international financial reporting standards (IFRS) adoption on financial reporting practice in the Nigerian banking sector, journal of policy and development studies vol. 9, no. 2,169-184 Retrieve from http://www.arabianjbmr.com/pdfs/JPDS_VOL_9_2/15.pdf on 18 Dec 2016

[2]. Atu,O.O., Atu, O.G. \&Atu, O.V. (2014). A Comparative Study of Accounting Standards in Nigeria, United Kingdom and United States of America. Journal of Economics and Finance, Vol3(2), 1-7

[3]. Ball, R. (2001). Infrastructure requirements for an economically efficient system of public financial reporting and disclosure. Brookings-Wharton Papers on Financial Services, 127-169

[4]. Barth, M., Landsman, W., \& Lang, M. (2006). International accounting standards and accounting quality. Working Paper, Stanford University and University of North Carolina at Chapel Hill.Retrieve fromhttp://public.kenan-flagler.unc.edu/faculty/langm/bllw_0302.pdf on 18 Dec 2016

[5]. Brown , DL and Moore MH (2001), 'Accountability, Strategy, and International Non-Governmental Organisations', in Non-profit and Voluntary Sector Quarterly, March, Hauser Centre Working Paper Series,Retrieve gouvernance.org/docs/accountability.strategy.and.international.ngos.pdf on 18 Dec 2016

[6]. Cardozzo, M. (2008). The Impact of IAS/IFRS on Accounting Practices: Evidence from Italian Listed Companies. Retrieved from http://www.hec.unil.ch/urccf/seminar/Michela\%20Cordazzo\%20-\%20Dec07.pdf on 18 Dec, 2016

[7]. Cronin D. and Regan J.O (2002): Accountability in Development Aid: Meeting Responsibilities, Measuring Performance A Research Report for Cómhlamh, Retrieved from http://www.dochas.ie/Shared/Files/4/Comhlamh_Research.pdfon 18 Dec, 2016

[8]. El-Gazzar, S. M., Finn, P. M., \& Jacob, R. (1999). An empirical investigation of multinational firms compliance with international accounting standards. International Journal of Accounting, 34(2),

[9]. Fowokan, T. (2011), IFRS adoption in Nigeria- Tax Implications. CITN seminar paper on IFRS adoption in Nigeria.

[10]. Herbert W.E, Ene E.E and Tsegba I. N. (2014) Globalization of Financial Reporting: Obstacles to International Financial Reporting Standards (IFRS) Adoption in Nigeria. Asian Journal of Business and Management Sciences Vol. 3 No. 12

[11]. IASB (2010). The Conceptual Framework for Financial Reporting, London.

[12]. Jacob, R. A. and Madu, C. N. (2009). International Financial Reporting Standards: an indicator of high quality. International Journal of Quality \& Reliability Management, 26,

[13]. Katz, M. L., Shapiro, C., 1985. Network externalities, competition and comparability. The American Economic Review , 75 (3), Retrieved fromidv.sinica.edu.tw/kongpin/teaching/io/KatzShapiro1.pdf on 20 Dec, 2016

[14]. Kenneth E. O. (2012). Adoption of IFRS and financial statements effects: The Perceived Implications on FDI and Nigeria Economy. Australian Journal of Business and Management Research Vol.2 No.05. Retrieved fromajbmr.com/articlepdf/aus-25-14i5n2a10.pdf on 18 Dec, 2016.

[15]. Masud, B. (2013). Effects of IFRS adoption on the financial reports of Nigerian listed entities: The case of oil and gas companies. A Multidisciplinary Journal of Global Macro Trends: The Macrotheme Review, 2(7). Retrieved frommacrotheme.com/yahoo_site_admin/assets/docs/2BalaMR27.32040348.pdf on 18 Dec, 2016.

[16]. Nneka S. E. and Rotimi O. (2012) Adoption of International Financial Reporting Standards (IFRS) to enhance financial reporting in Nigeria universities .Arabian Journal of Business and Management Review $\begin{array}{lllll}\text { (OMAN Chapter) } & \text { Vol. } & 2, & \text { No.3; } & \text { Retrieved }\end{array}$ fromwww.mcser.org/journal/index.php/mjss/article/viewFile/487/517on 18 Dec, 2016.

[17]. Olugbenga J, Oluwafemi S. M., and Akanfe K. (2016) Mandatory IFRS introduction and financial statements comparability: evidence from Nigerian listed companies. International journal of research science \& management. Impact Factor (PIF) Retrieved fromwww.ijrsm.com/issues\%20pdf\%20file/Archive2016/March-2016/3.pdf on 18 Dec, 2016.

[18]. Popa A., Blidisel R., and Bogdan V. (2009) Transparency and disclosure between theory and practice. A case study of Romania . Conference Proceedings compilation . Budapest Tech KeletiKároly Faculty of Economics. Retrieved fromciteseerx.ist.psu.edu/viewdoc/download?doi=10.1.1.473.9077\&rep=rep1..on 18 Dec, 2016.

[19]. Ramanna, K., Sletten, E., (2010). Network effects in countries' adoption of IFRS. Working paper, Harvard Business School .Retrieved fromwww.hbs.edu/faculty/.../10-092_7c19b207-b2c3-435d-a4cfbdcf7bfda3c2.pdfon 18 Dec, 2016 
[20]. Report of the Committee on Road Map to the Adoption of International Financial Reporting Standards in Nigeria in 2011, Retrieved fromhttp://www.nasbnigeria.org on 15 Dec, 2016

[21]. Sloan, R.G. (2001), Financial accounting and corporate governance: a discussion, Journal of Accounting and Economics, Vol.32 No.1-3. Retrieved fromwww.sciencedirect.com/science/journal/01654101/32on 18 Dec, 2016

[22]. Tendeloo, V \&Vanstraelen, B. A. (2005): Earnings Management under German GAAP versus European. European Accounting Review, Vol. 14, No. 1. Retrieved from citeseerx.ist.psu.

[23]. edu/viewdoc/download?doi=10.1.1.474.2136\&rep=rep1 on 18 Dec, 2016Zahran M.M. (2011).Accountability frameworks in the united nations system ,United Nations, Geneva Retrieved from https://www.unjiu.org/en/reports-notes/...JIU_REP_2011_5_English.pdfon 18 Dec, 2016 